\title{
Acute Toxicity Study of Porang (Amorphophallus oncophyllus) Flour Macerated with Strobilanthes crispus in Wistar Rats
}

\author{
Rizka Qurrota A'yun ${ }^{1}$, Uswatun Hasanah ${ }^{1}$, Hamam Hadi $^{2}$, Mustofa Mustofa ${ }^{3}$, Eva Nurinda ${ }^{4}$, Yulinda Kurniasari ${ }^{1}$, Veriani Aprilia ${ }^{1 *(i D}$ \\ ${ }^{1}$ Department of Nutrition, Faculty of Health Sciences, Universitas Alma Ata, Yogyakarta, Indonesia; ${ }^{2}$ Graduate School of \\ Public Health, Faculty of Health Sciences, Universitas Alma Ata, Yogyakarta, Indonesia; ${ }^{3}$ Department of Pharmacology and \\ Therapy, Faculty of Medicine, Public Health, and Nursing, Universitas Gadjah Mada, Jalan Farmako, Yogyakarta, Indonesia; \\ ${ }^{4}$ Department of Pharmacy, Faculty of Health Sciences, Universitas Alma Ata, Yogyakarta, Indonesia
}

Edited by: Slavica Hristomanova-Mitkovska Citation: A'yun RQ, Hasanah U, Hadi H, Mustofa M, Nurinda E, Kurniasari Y, Aprilia V. Acute Toxicity Study of with Strobilanthes crispus in Wistar Rats. Open Access Maced J Med Sci. 2021 Sep 25; 9(A):976-981. https://doi.org/10.3889/oamjms.2021.6813 Keywords: Amorphophallus oncophyllus; Strobilanthes crispus; LD50; Urinary protein; Serum glutamic oxaloacetic transaminase; Serum glutamic pyruvic transaminase *Correspondence: Veriani Aprilia, Department of Nutrition, Faculty of Health Sciences, Universitas Alma Ata, Yogyakarta, Indonesia. E-mail: verianiaprilia@ almaata.ac.id Received: 09-Jul-2021 Revised: 14-Sep-202

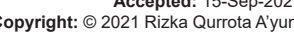
Hasanah, Hamam Hadi, Mustofa Mustofa Eva Nurinda, Yulinda Kurniasari, Veriani Aprilia unding: This research did not receive any financial support Competing Interests: The authors have declared that no competing interests exis Open Access: This is an open-access article distributed under the terms of the Creative Commons Attribution-

\begin{abstract}
BACKGROUND: Porang (Amorphophallus oncophyllus) is a local tuber food that high in bioactive compound glucomannan. It uses are limited due to oxalate acid content which poses health risks. Strobilanthes crispus leaves could reduce the level of calcium oxalate in porang. However, there is still no study to prove its safety.

AIM: This study aimed to investigate the acute oral toxicity study of porang ( $A$. oncophyllus) macerated with $S$. crispus based on observation of mortality rate (LD50), the changes in behavior during $72 \mathrm{~h}$, renal and hepatic function such as urinary protein, serum glutamic oxaloacetic transaminase (SGOT), and serum glutamic pyruvic transaminase (SGPT) levels of Wistar rat (Rattus norvegicus)

METHODS: An acute toxicity test was conducted based on the Organization of Economic Co-Operation and Development 420 Fixed-Dose Procedure Guideline that consists of preliminary and main studies. For the preliminary study, rats were divided into control and five treatment groups with the dosage of 50,300, 2000, and $5000 \mathrm{mg} / \mathrm{kg}$ body weight (BW) for each natural porang flour (NPF) and S. crispus-macerated porang flour (SPF). For the main study, rats were divided into four groups, those were NPF and SPF with the dosage of 2000 and $5000 \mathrm{mg} / \mathrm{kg} \mathrm{BW}$. Levels of urinary protein and blood serum SGOT and SGPT levels were measured at 0,24 , and 72 after treatment. RESULTS: The acute toxicity study showed that porang and porang macerated with $S$. crispus were not toxic unti the highest dose of $5000 \mathrm{mg} / \mathrm{kg} \mathrm{BW}$. It was proved by the absence of LD50, no change in behavior, no weight losses, and also the results of biochemical tests, such as urinary protein, SGOT, and SGPT which were still in the normal range.
\end{abstract}

CONCLUSIONS: Porang flour and SPF were concluded as non-toxic food based on acute toxicity study.

\section{Introduction}

Porang or iles-iles is included in the genus of Amorphophallus. These plants wildly grow in the jungle, under the bamboo tree, along the riverside, and mountain slope [1]. Porang tuber (Amorphophallus oncophyllus) contains glucomannan or known as mannan. Glucomannan is a water-dissolved food fiber that is low in calories and has a special function for diet, so that it has been widely used for food products [2] The food containing glucomannan reduced cholesterol level, blood sugar, and hypertension [3]. Its relatively low glycemic index could decrease blood sugar level and made this tuber was good to be consumed by diabetic patients. It proved to boost the therapy of diabetes type 2 through lipid metabolism improvement [4], while other study reported that glucomannan worked in synergy with metformin to increase its hypoglycemia effect [5].

Even though it had been proven that there were many benefits of glucomannan, the utilization of porang tuber as the source of glucomannan is still low. This is caused by the homemade product of porang still has the weakness, that is itchy when consumed. This itchiness is caused by the content of oxalate [6], [7], [8], [9]. Oxalate acid consumption in a high number increased blood creatinine and urea levels [6], [10]. It also decreased the bioavailability of calcium inside the body, formed kidney stones, can cause corrosion of the mouth and gastrointestinal tract, kidney failure, and hematuria [11].

Various efforts had been carried out to reduce the level of calcium oxalate level in porang tuber, both mechanically using stamp mill and blower, ball mill, also chemically using $\mathrm{NaCl}$ [8], [9], [12]. The research using natural or herbal ingredients in reducing oxalate calcium content is still limited. In a previous study, the ethanol extract of Strobilanthes crispus leaves reduced the level of calcium oxalate in porang flour [13], but it still needs to be proved before consumption for its safety. Therefore, in vivo toxicity test is needed to be carried out.

A toxicity test is a set of analyses to detect the toxic effect of a substance on the biological system 
and to obtain typical dose-response data from the test preparation [14]. In addition, a toxicity test can be carried out to determine the toxic effects on the vital organs of the animal, such as the kidneys and liver. One of the kidney functions is to excrete foreign compounds such as drugs, food, pesticides, and other non-nutritional exogenous materials that enter the body [15]. The study of the level of porang toxicity was reported on porang tubers [16], [17], but its combination with $S$. crispus needs to be studied further.

In this study, an acute toxicity test was conducted by observing the mortality rate (LD50) and the changes in behavior during $72 \mathrm{~h}$. To confirm the kidney and liver function, the urea protein tests, kidney histopathology, and biochemical tests of aminotransferase enzyme activity (serum glutamic oxaloacetic transaminase [SGOT] and serum glutamic pyruvic transaminase [SGPT]) were also done.

\section{Materials and Methods}

\section{Plant materials and sample preparation}

Porang was purchased from the farmer in Madiun, East Java. It was directly processed into flour at the laboratory. Porang flour macerated with S. crispus was then produced based on the Patent Application No. S00202006668 [18].

\section{Experimental animals}

Non-pregnant female Wistar (Rattus norvegicus) rats weighing 110-180 $\mathrm{g}$ with the age of 8-12 weeks were used in this acute study. Female rats were used because they were more sensitive than male rats [14]. For the preliminary study, 11 rats were used. Each of them was represented as a treatment group based on the dose of oral feeding, that is, control (distilled water treatment), natural porang flour (NPF1), NPF2, NPF3, NPF4, NPF5, and (S. crispusmacerated porang flour [SPF1], SPF2, SPF3, SPF4, and SPF5 for) for the dose of 50, 300, 2000, and $5000 \mathrm{mg} / \mathrm{kg}$ of bodyweight (BW), respectively. For the main study, twenty rats were divided into four groups, that is, NPF6 (dose of $2000 \mathrm{mg} / \mathrm{kg} \mathrm{BW}$ ), NPF7, SPF6, and SPF7.

An acute toxicity study was conducted based on the Organization of Economic Co-Operation and Development Guideline 420 for testing chemicals. The procedures consisted of two steps; those were preliminary and main analysis. For preliminary analysis, the rats were orally administered with porang flour or SPF with doses of 5,50 , and $300 \mathrm{mg} / \mathrm{kg} \mathrm{BW}$. If there was no mortality, the dose was increased up to
$2000 \mathrm{mg} / \mathrm{kg} \mathrm{BW}$. For the main analysis, the doses used were $2000 \mathrm{mg} / \mathrm{kg} \mathrm{BW}$ and $5000 \mathrm{mg} / \mathrm{kg} \mathrm{BW}$ [19].

The acclimatization of animals was 5 days and fed with free access to standard laboratory diet and ad libitum water. They were then fasted for $18 \mathrm{~h}$ before administered with the flours. The mortality, any injury, or illness, physical appearance, behavior changes (step backward, walk with the stomach, and sleepy), diarrhea were observed visually after the first $30 \mathrm{~min}$ and every $1 \mathrm{~h}$ for $24 \mathrm{~h}$. If there was no sign of toxicity, the test was completed until $72 \mathrm{~h}$. The BW of rats was monitored at the beginning and the end of the analysis. The urine and blood samples were collected before treatment, $24 \mathrm{~h}$ and $72 \mathrm{~h}$ after treatment for determining the urinary protein levels, SGOT, and SGPT levels, respectively. At the end of the study, rats were euthanized by decapitation, the kidney organs were excised carefully, then preserved in $10 \%$ buffered formalin before the histopathological study.

Urinary protein levels were analyzed by the pyrogallol red-molybdate method. SGOT and SGPT were analyzed by Optimized UV-test according to International Federation of Clinical Chemistry and Laboratory Medicine [14].

\section{Statistical analysis}

Data were performed by mean values, followed by statistical analysis used SPSS ver. 16. The differences between samples were tested by analysis of variance with Duncan's multiple range test. Differences were significant when $p<0.05$.

\section{Results and Discussion}

\section{Acute oral toxicity study}

The first acute oral toxicity study was preliminary. This study was important to find the starting dose that must be done in the main study because there was still no study about the toxicity of porang with the combination of $S$. crispus. The study showed that there was no mortality (LD50), injury, physical appearance, or behavior changes from the first 30 min until $72 \mathrm{~h}$ observations, for both NPF and SPF groups. The data were used as the reason to conduct the main study with the dose of $2000 \mathrm{mg} / \mathrm{kg}$ $\mathrm{BW}$ and $5000 \mathrm{mg} / \mathrm{kg} \mathrm{BW}$.

The main study was also showed no toxicity sign and mortality in all groups. Because the maximum dose did not cause mortality, LD50 was stated as apparent LD50. Based on The Hodge and Sterner Toxicity Scale, porang both natural and macerated with S. crispus were categorized as practically non-toxic 
due to no mortality (LD50) at the administration dose of 5000-15000 mg/kg BW [20].

\section{$B W$ of rats}

Figure 1a showed the BW of rats during $72 \mathrm{~h}$ of preliminary study. The BW of rats in this preliminary test did not show the weight loss that was in line with the results of the main study [10]. For this acute oral toxicity study, the administration of porang flour was once in the beginning of study and the BW was measured at the beginning and the end of study. The additional study with the administration of high doses porang (NPF6, NPF7, SPF6, and SPF7) and control with the frequency of once/day during 3 days was also conducted (Figure 1b). It was done to strengthen the answer whether there was the effect of porang administration on BW of rats. The data showed that there was the increase of BW in all treatments with the similar rates; those were about 5-6 g.

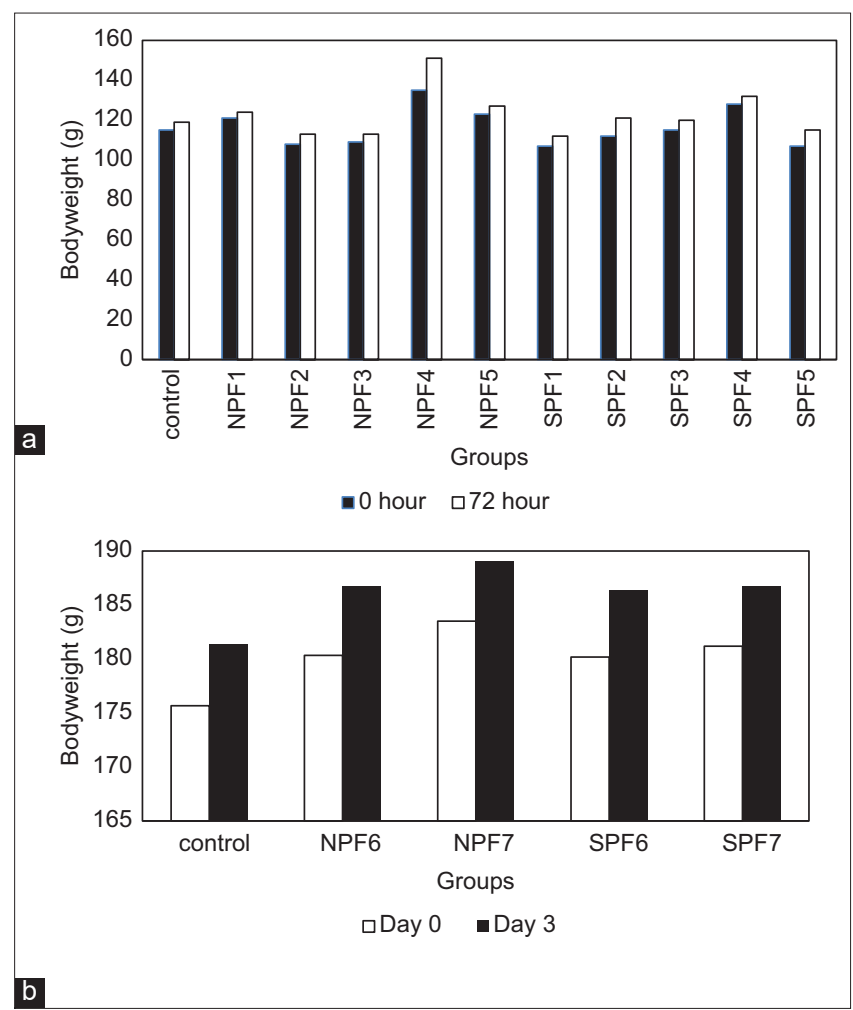

Figure 1: Bodyweight of rats in acute toxicity study of natural porang and S. crispus-macerated porang flour (a) with the administration only at the beginning of preliminary study (control: Distilled water treatment, NPF: Natural porang flour, SPF: S. crispus-macerated porang flour. NPF1, NPF2, NPF3, NPF4, NPF5 and SPF1, SPF2, SPF3, SPF4, SPF5, for the dose of 50, 300, 2000, and $5000 \mathrm{mg} / \mathrm{kg}$ body weight [BW], respectively); (b) with the administration of once/ day during 3 days of study (control: Distilled water treatment, NPF6, NPF7, and SPF6, SPF7 for the dose of 2000 and $5000 \mathrm{mg} / \mathrm{kg} \mathrm{BW,}$ respectively)

This data showed that there was no absence of weight loss during administration of porang. It indicated that their growth was normal or there was no indication of impaired absorption of nutrients due to the oral administration of porang flour both natural and macerated with S. crispus.

\section{Urinary protein levels and histopathological examination of kidney organ}

The effect of the administration of porang flour on urinary protein levels was shown in Table 1. All groups showed urinary levels under $200 \mathrm{mg} / \mathrm{L}$ that categorized as normal levels [21]. However, there was an increase observed in NPF7 and SPF7 both in $24 \mathrm{~h}$ and $72 \mathrm{~h}$ of administration and NPF6 after $72 \mathrm{~h}$ of administration $(p<0.05)$. It indicated that the elevation of protein levels may be seen at a shorter time when a higher dose was applied.

The increase of protein levels in the urine indicated a progression to a reduction in renal performance [22]. This study was relevant to the previous publication of the same study which showed an increase in urea and creatinine levels which can be used as an indicator of kidney function/performance [6], [10]. In another study, the administration of the herbal medicine of galohgor also showed an increase in urea level, creatinine, and urinary protein [23]. In this study, the decrease was still within the normal range, therefore it is necessary to confirm with further toxicity tests of sub chronic and others to find out whether in a longer period of studies there will be a gradual reduction in kidney performance.

In this study, there was no difference in urea protein levels between the NPF and SPF groups, which indicated that immersion in S. crispus, which is one of the herbal medicines, did not affect increasing urea protein levels. However, porang flour contains components that can cause the risk of damage to the kidneys, namely, calcium oxalate. Calcium oxalate had an impact on mechanical abrasion of the gastrointestinal tract and renal smooth tubules [24]. In another study, the administration of herbal medicine caused acute tubular necrosis or fibrotic interstitial nephritis that occurred rapidly and progressively. This syndrome was characterized by progressive renal failure, the discovery of a lot of urine sediment, shrinkage of kidney size with mild proteinuria, and was associated with the incidence of urothelial cancer [25], [26]. Calcium oxalate may also form the kidney stone that the incidence is rising recently with the lifetime risk of $10-15 \%$ [27]. This clinical stone formation begins form the nucleation of crystal either in supersaturated renal tubular fluid or in the renal interstitial fluid. This may be influenced by the rising of stone component molecules, the lowering of urine volume, the changing of $\mathrm{pH}$, or the combining of these factors. The crystal may growth in size that may combine with some intrarenal structure and further nucleation to generate the stone [28].

As a confirmation test for the effect of oral administration of porang flour, this study also conducted a kidney histopathology test (Figure 2). Histopathology of the kidney showed that all renal organs changed in terms of anatomical pathology in the form of congestion, except for the NPF7 group which was in the form of hemorrhage. Mild congestion was found in the control, NPF6, and SPF6 groups, while the most severe congestion was seen in SPF7. Congestion and 
Table 1: Urinary protein levels of rats in acute toxicity study of porang and SPF

\begin{tabular}{|c|c|c|c|c|}
\hline Urinary Protein $(\mathrm{mg} / \mathrm{L})$ & NPF6 (mean \pm SD) & SPF6 (mean \pm SD) & NPF7 (mean \pm SD) & SPF7 (mean \pm SD) \\
\hline \multicolumn{5}{|l|}{$24 \mathrm{~h}$} \\
\hline Pre & $62.32 \pm 7.23$ & $59.45 \pm 4.78$ & $60.33 \pm 6.03$ & $60.33 \pm 2.29$ \\
\hline Post & $62.74 \pm 6.83$ & $59.29 \pm 3.90$ & $77.77 \pm 2.11$ & $74.92 \pm 4.73$ \\
\hline$p$-value ${ }^{1}$ & 0.235 & 0.783 & $0.004^{*}$ & $0.005^{*}$ \\
\hline$\Delta$ & $0.42 \pm 0.68$ & $-0.16 \pm 1.18$ & $17.43 \pm 6.68$ & $14.59 \pm 5.68$ \\
\hline$p$-value ${ }^{2}$ & 0.370 & & 0.489 & \\
\hline \multicolumn{5}{|l|}{$72 \mathrm{~h}$} \\
\hline Pre & $62.32 \pm 7.23$ & $59.45 \pm 4.78$ & $60.33 \pm 6.03$ & $60.33 \pm 0.29$ \\
\hline Post & $65.91 \pm 5.60$ & $60.13 \pm 4.21$ & $80.50 \pm 1.99$ & $76.48 \pm 5.21$ \\
\hline$p$-value ${ }^{1}$ & $0.009^{\star}$ & 0.217 & $0.002^{\star}$ & $0.005^{\star}$ \\
\hline$\Delta$ & $3.59 \pm 1.68$ & $0.68 \pm 1.04$ & $20.17 \pm 6.41$ & $16.15 \pm 6.30$ \\
\hline p-value ${ }^{2}$ & $0.011^{*}$ & & 0.346 & \\
\hline
\end{tabular}

respectively, NPF: natural porang flour, SPF: S. crispus macerated porang flour.

hemorrhage were a natural process that usually occurs after decapitation. Decapitation leads to tissue injury which causes an increase in blood flow to organs, one of which is the kidneys. In kidney congestion, there is an increase in venous blood pooling in the renal vascular that may be due to physiological conditions, passive blood pressure, and secondary effects to hypovolemic shock, insufficiency, and hypostatic cardiac. In this condition, capillary dilation occurs due to vasodilator stimulation so that the vascularization at the site of the injury widens and contains stagnant blood. Meanwhile, hemorrhage can occur due to the breakdown of blood vessels after congestion or intolerable congestion.

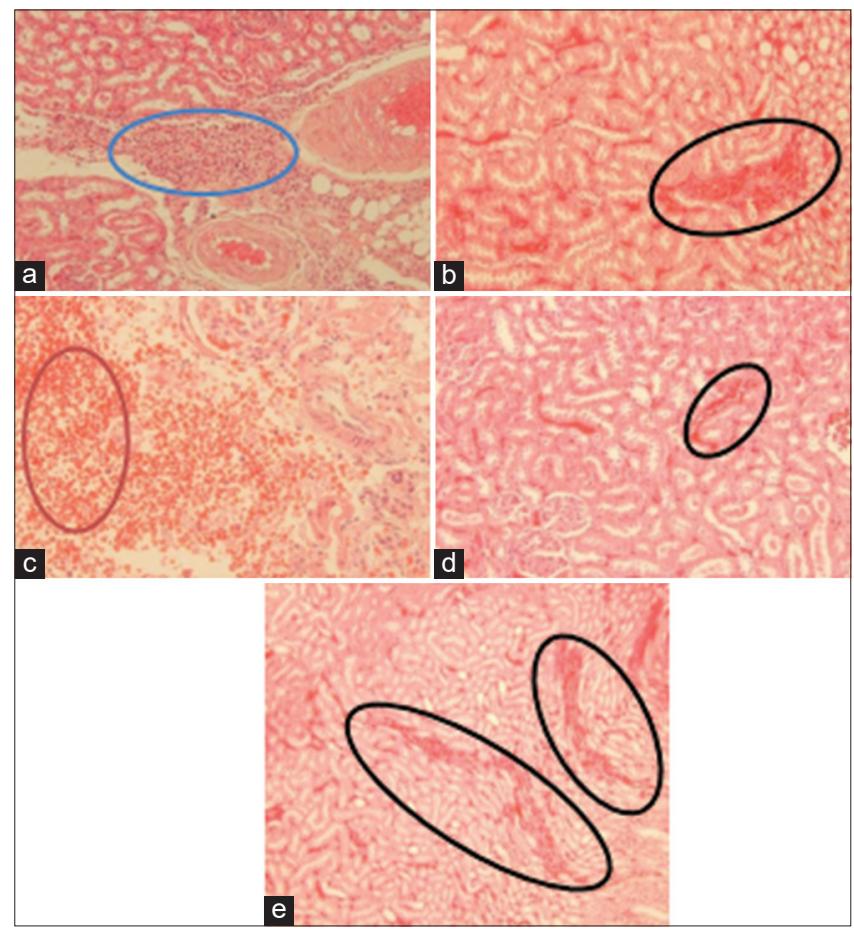

Figure 2: Histopathological examination of kidney organ of the rat in acute oral toxicity study of porang and S. crispus macerated porang flour (SPF) (magnification 400x): (a) control group, (b) natural porang flour (NPF)6, (c) NPF7, (d) SPF6, (e) SPF7. Blue, red, and black circles describe inflammation, hemorrhage, and congestion, respectively.

\section{SGOT levels of blood serum}

SGOT blood serum levels increased significantly in NPF7 and SPF7 groups, both in the observation of $24 \mathrm{~h}$ and $72 \mathrm{~h}$ after oral administration $(\mathrm{p}<0.05)$ (Table 2$)$. It meant that the high dose of porang and SPF had an impact on SGOT levels. However, the increase was still in the normal range between 36.99 and $42.62 \mathrm{U} / \mathrm{L}$ [29]. This study was in line with other subacute toxicity studies that used glucomannan flour with the dose of $4000 \mathrm{mg} / \mathrm{kg}$ BW and porang flour in acute toxicity study at a dose of $5000 \mathrm{mg} / \mathrm{kg}$ BW [21], [17].

Table 2 also showed that there were no differences between NPF and SPF groups in the dose of 2000 and $5000 \mathrm{mg} / \mathrm{kg} \mathrm{BW}$. It indicated that S. crispus maceration did not affect the SGOT levels. The increase in SGOT levels affected by the calcium oxalate content which has the risk of damaging the liver cell membrane so that its permeability was impaired, resulting in the SGOT enzyme leaving cells freely, entered the extracellular space and blood vessels beyond normal conditions [17], [30].

In addition, psychological factors occurred due to repeat blood sampling in a relatively short time, leading to stress which also triggered the release of the SGOT enzyme in the blood and increased SGOT levels. Several studies proved that the increase of SGOT enzyme levels did not specifically indicate liver dysfunction, because the enzyme was also found in the skeletal muscles, pancreas, heart, blood vessels of the brain, lungs, and testes [31]. Thus, the increase in SGOT levels was not only caused by damage to the liver cells but also other organs.

\section{SGPT levels of blood serum}

SGPT levels of blood serum had a similar result to SGPT, which increased significantly after oral administration of porang in NPF7 and SPF7 groups $(p<0.05)$. However, there was no significant difference between NPF6 and SPF6 groups ( $p>0.05$ ). These results explain that at higher doses (up to $5000 \mathrm{mg} / \mathrm{kg}$ BW), porang both with or without maceration affected the increase of SGPT (Table 3).

SGPT levels in this study were classified as normal (18.16-24.96 U/L) [29]. However, an increase in SGPT needs attention, because it is an indicator of active hepatocellular damage. Several studies conducted in France, North America, and the Pacific Islands had proven the occurrence of hepatitis in 
Table 2: SGOT blood serum levels of rats in acute toxicity study of porang and SPF

\begin{tabular}{|c|c|c|c|c|}
\hline SGOT (U/L) & NPF6 (mean \pm SD) & SPF6 (mean \pm SD) & NPF7 (mean \pm SD) & SPF7 (mean \pm SD) \\
\hline \multicolumn{5}{|l|}{$24 \mathrm{~h}$} \\
\hline Pre & $37.38 \pm 0.77$ & $37.67 \pm 0.55$ & $37.38 \pm 00.34$ & $36.61 \pm 1.22$ \\
\hline Post & $37.58 \pm 0.55$ & $39.03 \pm 0.74$ & $45.54 \pm 0.93$ & $43.50 \pm 0.55$ \\
\hline$p$-value ${ }^{1}$ & 0.704 & $0.009^{*}$ & $0.000^{*}$ & $0.000^{*}$ \\
\hline$\Delta$ & $0.19 \pm 1.06$ & $1.36 \pm 0.63$ & $8.16 \pm 1.16$ & $5.83 \pm 0.97$ \\
\hline$p$-value ${ }^{2}$ & 0.068 & & 0.158 & \\
\hline \multicolumn{5}{|l|}{$72 \mathrm{~h}$} \\
\hline Pre & $37.38 \pm 0.77$ & $37.67 \pm 0.55$ & $37.38 \pm 0.34$ & $36.61 \pm 1.22$ \\
\hline Post & $37.67 \pm 0.77$ & $36.99 \pm 1.34$ & $42.14 \pm 0.41$ & $42.62 \pm 0.63$ \\
\hline$p$-value ${ }^{1}$ & 0.552 & 0.245 & $0.000^{*}$ & $0.001^{*}$ \\
\hline$\Delta$ & $0.29 \pm 1.01$ & $-0.68 \pm 1.12$ & $4.76 \pm 0.53$ & $6.02 \pm 1.63$ \\
\hline p-value ${ }^{2}$ & 0.189 & & 0.138 & \\
\hline
\end{tabular}

${ }^{*}$ Significant $(p<0.05)$ with 'paired t-tests to compare pre- and post- result; 'independent t-tests to compare NPF and SPF. NPF6, NPF7 or SPF6, SPF7 were administered with the dose of 2000 and $5000 \mathrm{mg} / \mathrm{kg}$ BW, respectively, NPF: natural porang flour, SPF: S. crispus macerated porang flour.

patients who consumed herbal ingredients in high doses for long period [32], [33], [34]. Therefore, it needs further studies to know the effects of consuming porang for a longer period on the liver. The tendency of SGPT to increase in this study could be caused by the content of needle-shaped calcium oxalate crystals that may dissolve in the blood and scratch or damage the liver cells. In addition, toxicity may be occurred as the interaction between components in porang containing calcium oxalate and $S$. crispus containing alkaloids, saponins, flavonoids, potassium, and polyphenols.

\section{Conclusions}

Based on the acute toxicity study, it can be concluded that porang and porang macerated with $S$. crispus were not toxic until the highest dose of $5000 \mathrm{mg} / \mathrm{kg} \mathrm{BW}$. It was proved by the absence of LD50, no change in behavior, no weight losses, and also the results of biochemical tests, such as urea protein, SGOT, and SGPT which were still in the normal range. It is necessary to carry out further toxicity studies, including sub chronic to determine the safety level of porang and S. crispus consumption for long period.

\section{Acknowledgments}

The authors would like to thank Alma Ata University for the many facilities for this study.

\section{References}

1. Zhang $Y$, Xie B, Gan X. Advance in the applications of konjac glucomannan and its derivatives. Carbohydr Polym. 2005;60(1):27-31. http://doi.org/10.1016/j.carbpol.2004.11.003

2. Devaraj RD, Reddy CK, Xu B. Health-promoting effects of konjac glucomannan and its practical applications: A critical review. Int J Biol Macromol. 2019;126:273-81. https://doi.org/10.1016/j. ijbiomac.2018.12.203

PMid:30586587

3. Vuksan V, Sievenpiper JL, Owen R, Swilley JA, Spadafora P, Jenkins DJ, et al. Beneficial effects of viscous dietary fiber from Konjac-Mannan in subjects with the insulin resistance syndrome: Results of a controlled metabolic trial. Diabetes Care. 2000;23(1):9-14. http://doi.org/10.2337/diacare.23.1.9 PMid: 10857960

4. Chen $\mathrm{H}$, Nie $\mathrm{Q}, \mathrm{Hu} \mathrm{J}$, Huang $\mathrm{X}$, Zhang $\mathrm{K}$, Pan $\mathrm{S}$, et al. Hypoglycemic and hypolipidemic effects of glucomannan extracted from konjac on Type 2 diabetic rats. J Agric Food Chem. 2019;67(18):5278-88. http://doi.org/10.1021/acs. jafc. $9 \mathrm{~b} 01192$ PMid:30964673

5. Zheng J, Li H, Zhang X, Jiang M, Luo C, Lu Z, et al. Prebiotic mannan-oligosaccharides augment the hypoglycemic effects of metformin in correlation with modulating gut microbiota. J Agric Food Chem. 2018;66(23):5821-31. http://doi.org/10.1021/acs. jafc. 8 b00829 PMid:29701959

6. Ernawati E, Aprilia V, Pangastuti R. The increase of blood creatinine levels and the gastric histopathology of rat after feeding of porang (Amorphophallus oncophyllus) flour treated with Strobilantehes crispa. Indones J Nutr Diet. 2018;6(3):113-21.

7. Pramathana A. The Characteristics of Porang Flour with the Variation of Ash and Salt Soaking in Reducing Oxalic Acid. Universitas Jember; 2013 (In Indonesian).

8. Mawarni RT, Widjanarko SB. He effect of ball mill method and chemically purification in reducing calcium oxalate. J Pangan Agroind. 2015;3(2):571-81. (In Indonesian)

Table 3: SGPT blood serum levels of rats in acute toxicity study of porang and SPF

\begin{tabular}{|c|c|c|c|c|}
\hline SGPT (U/L) & NPF6 (mean \pm SD) & SPF6 (mean \pm SD) & NPF7 (mean \pm SD) & SPF7 (mean \pm SD) \\
\hline \multicolumn{5}{|l|}{$24 \mathrm{~h}$} \\
\hline Pre & $18.74 \pm 0.26$ & $18.45 \pm 0.34$ & $18.45 \pm 0.59$ & $18.06 \pm 0.63$ \\
\hline Post & $18.16 \pm 0.65$ & $18.64 \pm 0.43$ & $24.96 \pm 0.55$ & $23.88 \pm 0.41$ \\
\hline$p$-value ${ }^{1}$ & 0.109 & 0.178 & $0.000^{*}$ & $0.000^{*}$ \\
\hline$\Delta$ & $-0.58 \pm 0.63$ & $0.20 \pm 0.27$ & $6.51 \pm 0.27$ & $5.83 \pm 0.97$ \\
\hline$p$-value ${ }^{2}$ & $0.035^{\star}$ & & 0.170 & \\
\hline \multicolumn{5}{|l|}{$72 \mathrm{~h}$} \\
\hline Pre & $18.74 \pm 0.26$ & $18.45 \pm 0.34$ & $18.45 \pm 0.59$ & $18.06 \pm 0.63$ \\
\hline Post & $18.45 \pm 0.34$ & $18.35 \pm 0.53$ & $23.40 \pm 0.40$ & $23.40 \pm 0.40$ \\
\hline$p$-value ${ }^{1}$ & 0.209 & 0.800 & $0.000^{*}$ & $0.001^{*}$ \\
\hline$\Delta$ & $-0.29 \pm 0.43$ & $-0.10 \pm 0.80$ & $4.95 \pm 0.80$ & $5.34 \pm 0.49$ \\
\hline$p$-value ${ }^{2}$ & 0.643 & & 0.378 & \\
\hline
\end{tabular}


9. Sanjaya $\mathrm{MI}$, Kunarto $\mathrm{B}$, Wahjuningsih SB. The combination effect of soaking in $\mathrm{NaCl}$ and size particle on glucomanan, calcium oxalate, and food fiber content in porang flour. J Teknol Pangan Has Pertan. 2012;9(2):16-23. (In Indonesian).

10. Astuti RD, Prastowo A, Aprilia V. Porang fl our (Amorphophallus oncophyllus) with and without soaking of keji beling extract increases the value of ureum on toxicity test in wistar rat (Rattus norvegicus). Indones J Nutr Diet. 2017;5(3):93-7. http://doi. org/10.21927/ijnd.2017.5(3).93-97

11. Noonan SC. Oxalate content of foods and its effect on humans. Asia Pac J Clin Nutr. 1999;8(1):64-74. PMid:24393738

12. Faridah A, Widjanarko SB. Optimization of multilevel ethanol leaching process of porang flour (Amorphophallus muelleri) using response surface methodology. Int J Adv Sci Eng Inf Technol. 2013;3(2):74-80.

13. Dewi MS. Learning about the Solution Ability of Calcium Oxalate in Strobilanthes crispus Leaf Extract and Water Fraction. Universitas Andalas; 2009.

14. BPOM RI. Regulation of the Head of The Food and Drug Supervisory Agency of The Republic of Indonesia No. 7, 2014 Concerning Guidelines for In Vivo Non Clinical Toxicity Test; 2014.

15. Mistry K. Chronic kidney disease. Clin Pediatr Nephrol Third Ed. 2016;315(20):601-26.

16. Krysanti A, Widjanarko SB. Subacute toxicity testing of glucomannan (A. muelleri Blume) toward SGOT and sodium of wistar rats by in vivo. J Pangan dan Argoind. 2014;2(1):1-6.

17. Natalia ED, Widjanarko SB, Ningtyas DW. Acute toxicity test of glucomannan flour (A. muelleri Blume) toward potassium of wistar rats. J Pangan Agroind. 2014;2(1):132-6.

18. Aprilia V, Nurinda E, Alpina L, Hadi H, Ariftiyana S, Kurniasari Y. Reduction procedure of calcium oxalate in porang flour by maceration of Strobilanthes crispa; 2020. Available from: https://pdki-indonesia.dgip.go.id/detail/S00202006668? type=patent\&keyword=proses+ reduksi+kalsium+oksalat. [Last accessed on 2021 Jun 02].

19. OECD. OECD Guidlines for Testing og Chemicals. Test No. 420: Acute Oral Toxicity Fixed Dose Procedure; 2001. p. 1-14.

20. Hodge A, Sterner B. Toxicity classes. In: Canadian Center for Occupational Health and Safety; 2005.

21. Mundt L, dan Shanahan K. Graff's Textbook of Urinalysis and Body Fluids. Philadhelpia, PA; Wolters Kluwer; 2010.

22. Harris P, Mann L, Phillips B, Webster C. Diabetes Management in General Practice Gideline for Type 2 Diabetes. Australia:
Diabetes Australia; 2011.

23. Wicaksono MA. The Evaluation of Renal and Hepatic Function of Female Rats (Sprague-Dawley) as the Impact of Administration of Galohgor Jamu. Bogor Agricultural University; 2010. (In Indonesian)

24. Korth KL, Doege SJ, Park SH, Goggin FL, Wang Q, Gomez SK, et al. Medicago truncatula mutants demonstrate the role of plant calcium oxalate crystals as an effective defense against chewing insects. Plant Physiol. 2006;141(1):188-95. http://doi. org/10.1104/pp.106.076737

PMid: 16514014

25. Keppel J, Calissi P. Safe drug prescribing for patients with renal insufficiency. Can Med Assoc J. 2002;166(6):473-7.

PMid:11873927

26. Albright RC Jr. Acute renal failure: A practical update. Mayo Clin Proc. 2001;76(1):67-74. http://doi.org/10.4065/76.1.67 PMid: 11155415

27. Wilcox CR, Whitehurst LA, Somani BK, Cook P. Kidney stone disease: An update on its management in primary care. $\mathrm{Br} \mathrm{J}$ Gen Pract. 2020;70(693):205-6.

PMid:32217603

28. Ratkalkar VN, Kleinman JG. Mechanisms of stone formation Clin Rev Bone Miner Metab. 2011;9(3-4):187-97. http://doi. org/10.1007/s12018-011-9104-8 PMid:22229020

29. Mitruka BM. Clinical Biochemical and Hematological Reference Values in Normal Experimental Animals and Normal Humans. $2^{\text {nd }}$ ed. Chicago: Masson Publishing; 1981.

30. Donowarti I, Widjanarko SB, Yunianta Y, Pudjiastuti P. Acute toxicity test of low calcium oxalate porang (Amorphophallus mueleri Blume) flour. Iraqi J Agric Sci. 2021;52(1):218-31.

31. Loeb WF, Quimbly FW. The Clinical Chemistry of Laboratory Animals. London: Pergamon Press Inc.; 1989.

32. Shad JA, Brann OS. Acute hepatitis after ingestion of herbs. South Med J. 1999;92(11):1095-7. http://doi. org/10.1097/00007611-199911000-00011 PMid: 10586838

33. Laliberte L, Villeneuve JP. Hepatitis after the use of germander, a herbal remedy. Can Med Assoc J. 1996;154(11):1689-92. PMid:8646656

34. Currie BJ, Clough AR. Kava hepatotoxicity with western herbal products: Does it occur with traditional kava use? Med J Aust. 2003;178(9):421-2. http://doi.org/10.5694/j.1326-5377.2003. tb05279.x

PMid:12720503 